\title{
The effect of duty type on current-carrying capacity of mining power cables
}

\begin{abstract}
The methodology for determining intermittent or short-time current-carrying capacity has been described in the article. Results of current rating calculations for a short-time load and the time of cooling to an ambient temperature have been presented.
\end{abstract}

Key words: current-carrying capacity, mining power cables

\section{INTRODUCTION}

The existing standard [1] for the current-carrying capacity of mining power cables contains principles of selection for continuous and short-circuit loads. The standard concerning motor ratings [2] singles out continuous running as well as other types of duty for electrical motors. The load can be described numerically (load power varies over time in a known manner), graphically, or by choosing one of predefined load types S1 to S10 (actual load should not lead to thermal effects greater than that selected). Duty type S1 corresponds to continuous operation at a constant load; duty type S2 - to short-time duty; S3 through S5 - intermittent periodic duty; and S6 through S10 continuous operation periodic duty with variable load. Short-time duty can be defined as an operation with a steady load lasting a particular amount of time that is shorter than the time needed to obtain a steady temperature. Subsequently, a standstill time ensues, during which the cable's temperature sufficiently approaches the temperature of the surroundings (Fig. 1).

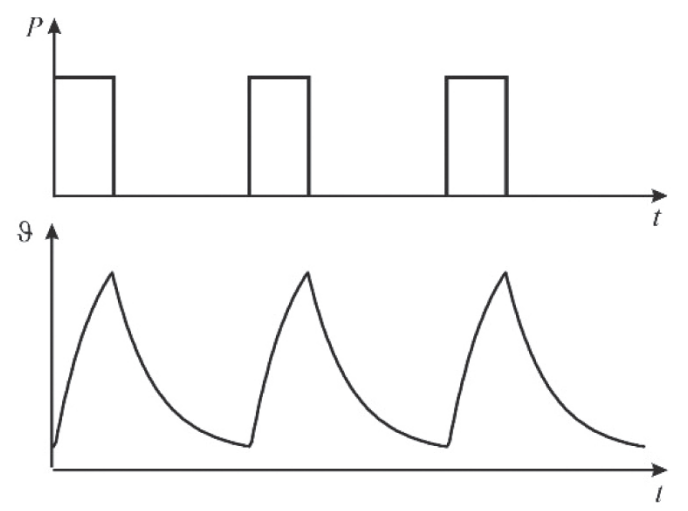

Fig. 1. Temperature run during load-type $S 2$
Intermittent duty is defined as a sequence of identical cycles that may include (depending on the duty type) periods of load, rest, starting, and braking. The motor's manufacturer should specify the rated power for a given type of operation; if the latter is not specified, power refers to load-type S1.

Should extra elements be a part of the machinery, parameters will also apply to these. Power cables are loaded in a manner similar to the supplied machine's motor. If the actual load type is different than S1, failure to take it to account when selecting the nominal cross-sectional area of conductors may lead to:

- unjustified inflation of conductors' cross-sectional area and, as a result, increasing the costs of installation if the actual load induces a temperature rise smaller than continuous operation;

- excessive temperature rise, if the actual load evokes thermal effects greater than continuous operation; this can be a result of frequent and heavy motor starting and electric braking (S4 or S5 duty types).

In practice, especially if longwall machines (such as shearers and chain conveyors) are concerned, the actual load type is similar to intermittent; however, taking into account the random nature of load fluctuations, it proves virtually impossible to attribute one of standardized duty types to such machines. Other machines in turn (such as cyclic operating pumps) are satisfactorily attributable to one of the predefined duty types. This article analyzes the heating and cooling processes for short-time duty operating cables. The same methodology of calculation and analysis can be applied to other load types. 


\section{CALCULATION OF CURRENT-CARRYING CAPACITY}

The values of continuous current-carrying capacity for different groups of mining cables are specified in standard [1]; however, due to the fact that similar cables produced by different manufacturers tend to vary in design, the ratings stated by the producer may deviate from the standard. These differences do not exceed $2-3 \%$ and are caused by the varying conductor diameters as well as the thickness of the structural elements. Current-carrying-capacity values can be determined experimentally; however, it is rather impractical and requires long-term measurements that must be performed for each nominal cross-section and every cable type. The oldest and still most-widely-used method of calculating current-carrying capacity is one based on a thermal analogy to Ohm's law; it involves the use of many simplifying assumptions and geometric coefficients determined in an approximate or empirical fashion. In the case of atypical cable structures or an unconventional way of their positioning, this method is prone to giving ambiguous results [3]. When determining the capacity for a duty type other than continuous (such as intermittent and short-time), it is necessary to make further simplifying assumptions; e.g., ones concerning the thermal time constant's stability. Furthermore, the nonlinearity (raised in a number of issues) leads to an insufficient accuracy of the calculations provided by those simplified models.

Heat flow by conduction is described by Fourier's law, according to which heat flux density $q$ is directly proportional to gradient of the temperature $\vartheta$ :

$$
q=-\lambda \operatorname{grad} \vartheta
$$

where $\lambda$ - thermal conductivity coefficient.

The temperature field inside a cable can be written by means of the Fourier-Kirchhoff equation:

$$
\vartheta-\frac{\sigma c}{\lambda} \frac{\partial \vartheta}{\partial t}=-\frac{q_{v}}{\lambda}
$$

where:

$c$ - specific heat capacity $[\mathrm{J} /(\mathrm{kg} \cdot \mathrm{K})]$,

$\sigma-$ body mass density $\left[\mathrm{kg} / \mathrm{m}^{3}\right]$,

$q_{v}$ - heat source's volumetric rate of heat generation $\left[\mathrm{W} / \mathrm{m}^{3}\right]$.
Finding the result for Equation (2) is sufficient for finding the temperature, given that the initial and boundary conditions are specified.

Obtaining an analytical result of differential Equation (2) describing the temperature field is only possible in specific cases regarding simplified regularly-shaped models (such as in uninsulated cables). Insulated power cables are characterized by a complicated geometry with internal heat sources and fluctuating boundary conditions. In cases like these, the problem can be solved solely by numerical calculations [4]. The calculations in this paper have been conducted using the finite element method (FEM).

The essence of FEM is the possibility of approximating every physical quantity (in this case, temperature) by means of a discreet model based on the so-called test function.

The discreet model is created by specifying a finite number of nodes dividing the area in question into a finite number of elements that depict the area's shape as accurately as possible.

The method encompasses calculating the temperature in the nodes, and the temperature inside the element is approximated by a certain polynomial, provided that the polynomials ensure the continuity of temperature on the elements' borders.

\section{CALCULATING THE CURRENT-CARRYING CAPACITY FOR SHORT-TIME DUTY}

In order to determine the possibility of increasing the load capacity of cables supplying motors operating on short-time duty, calculations were conducted for the heating and cooling of mining power cables. These calculations were made for OnGcekż-G 0.6/1 kV flexible cables for the nominal cross-sectional area of conductors of $25 \mathrm{~mm}^{2}$ to $95 \mathrm{~mm}^{2}$ (the same methodology of calculation may also be used for other types of cables). Table 1 shows the numerical values of short-time duty current capacity for operation S2 $60 \mathrm{~min}$, S2 $30 \mathrm{~min}$, and S2 $15 \mathrm{~min}$ (values of continuous current rating are given for comparison). Relative values (in \%) in relation to the continuous current rating are also shown. 
Table 1

Calculated values of continuous and short-time current rating for OnGcekż-G type cables

\begin{tabular}{|c|c|c|c|c|c|c|c|c|}
\hline \multirow{2}{*}{$\begin{array}{c}\text { Nominal cross- } \\
\text {-sectional area } \\
\text { of conductors [mm }\end{array}$} & \multicolumn{2}{|c|}{$\begin{array}{c}\text { S1 } \\
\text { (continuous load) }\end{array}$} & \multicolumn{2}{c|}{$\begin{array}{c}\text { S2 } \\
\text { 60 min }\end{array}$} & \multicolumn{2}{c|}{ S2 } & \multicolumn{3}{c|}{$\begin{array}{c}\text { S2 } \\
\text { 15 min }\end{array}$} \\
\cline { 2 - 10 } & A & {$[\%]$} & A & {$[\%]$} & A & {$[\%]$} & A & {$[\%]$} \\
\hline 25 & 152 & 100 & 161 & 106 & 183 & 120 & 224 & 147 \\
\hline 35 & 187 & 100 & 202 & 108 & 236 & 126 & 292 & 156 \\
\hline 50 & 233 & 100 & 258 & 111 & 306 & 131 & 382 & 164 \\
\hline 70 & 288 & 100 & 330 & 115 & 398 & 138 & 502 & 174 \\
\hline 95 & 345 & 100 & 410 & 119 & 502 & 146 & 637 & 185 \\
\hline
\end{tabular}

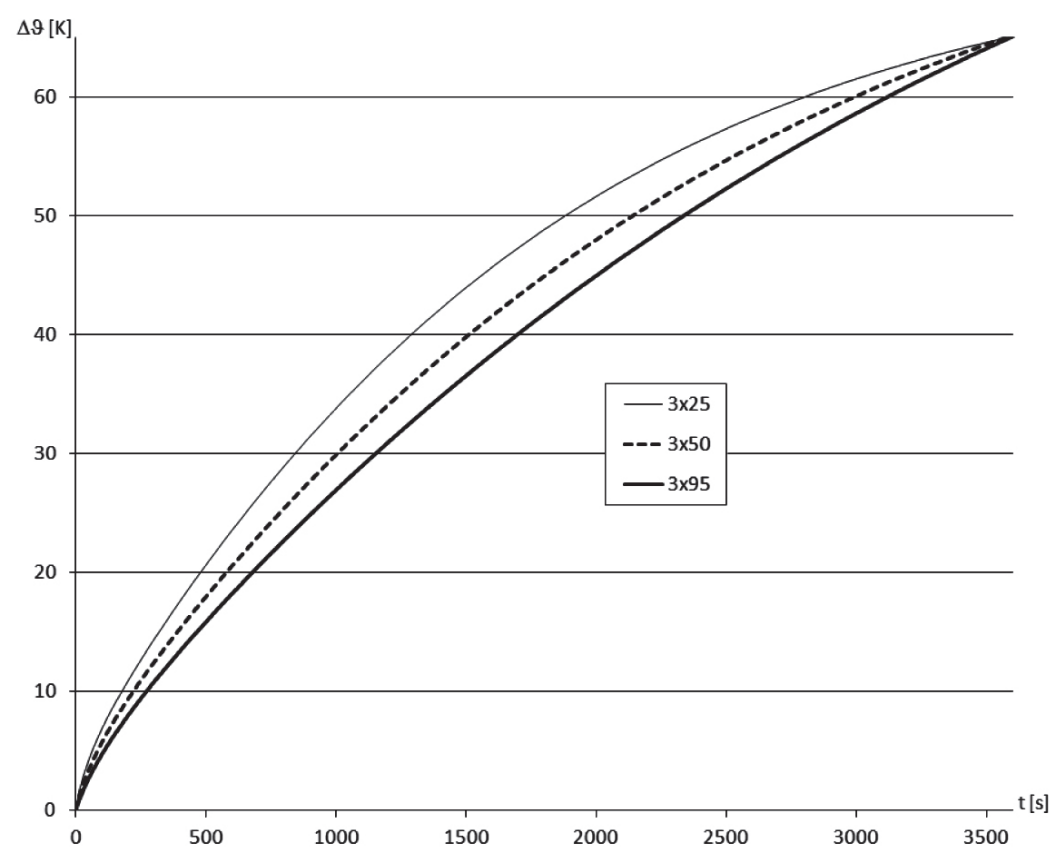

Fig. 2. Conductors' temperature rises in time during heating with current equal to capacity for duty-type S2 60 min

Figure 2 shows the temperature rise over time for cables of conductor diameters of $25 \mathrm{~mm}^{2}, 50 \mathrm{~mm}^{2}$, and $95 \mathrm{~mm}^{2}$. The depicted values concern the temperature of insulation at its hottest spot; in practice, equal in value to the temperature of the conductors. It was assumed that, in time $t=0$, the cable's temperature was equal to the temperature of the surroundings $\left(25^{\circ} \mathrm{C}\right)$.

It should be noted that the course of the temperature during heating slightly diverges from exponential [4] due to the nonlinearity of the problem - the heat transfer coefficient in reality depends on the temperature of the surface that transfers heat to the surroundings. Due to this factor, we cannot speak of a thermal time constant value; nevertheless, a slower increase of temperature is observed for cables with a greater conductor diameter.

Should duty be maintained for a period of time that is longer than established, will the permissible temperature be exceeded? The small and short exceedance of the permissible temperature do not have long-term effects, but greater and long-lasting ones can negatively influence a cable's lifetime. Table 2 depicts the time after which the permissible increase of temperature exceeds $10 \mathrm{~K}, 20 \mathrm{~K}$, and $30 \mathrm{~K}$, respectively.

In standard [2] regarding rotating electrical machines, the minimal rest (standstill) time for shorttime duty is defined as the time needed to cool the machine so that the difference between its temperature and the temperature of the coolant does not exceed $2 \mathrm{~K}$. Due to the fact that the cables are aircooled, this paper assumes that the rest time is long enough for the cable to cool down to a temperature of a maximum of $5 \mathrm{~K}$ greater than that of the surroundings. Figure 3 shows the temperature rise during the cooling of cables with the different conductors' cross-sectional areas. 
Table 2

Time (in seconds) after which permissible temperature of insulation $\left(90^{\circ} \mathrm{C}\right)$ will be exceeded by $10 \mathrm{~K}, 20 \mathrm{~K}$, or $30 \mathrm{~K}$ when load of cable lasts longer than specified by duty type

\begin{tabular}{|c|c|c|c|c|c|c|c|c|c|}
\hline \multirow{2}{*}{$\begin{array}{c}\text { Nominal cross- } \\
\text {-sectional area } \\
\text { of conductors }\left[\mathrm{mm}^{2}\right]\end{array}$} & \multicolumn{3}{|c|}{$\mathrm{S} 260 \mathrm{~min}$} & \multicolumn{3}{|c|}{$\mathrm{S} 230 \mathrm{~min}$} & \multicolumn{3}{|c|}{ S2 $15 \mathrm{~min}$} \\
\hline & $10 \mathrm{~K}$ & $20 \mathrm{~K}$ & $30 \mathrm{~K}$ & $10 \mathrm{~K}$ & $20 \mathrm{~K}$ & $30 \mathrm{~K}$ & $10 \mathrm{~K}$ & $20 \mathrm{~K}$ & $30 \mathrm{~K}$ \\
\hline 25 & - & - & - & 610 & 1570 & - & 220 & 430 & 680 \\
\hline 35 & 4160 & - & - & 520 & 1210 & 2280 & 200 & 400 & 630 \\
\hline 50 & 2050 & - & - & 460 & 1020 & 1770 & 190 & 380 & 590 \\
\hline 70 & 1550 & 5920 & - & 430 & 930 & 1520 & 180 & 370 & 560 \\
\hline 95 & 1230 & 3300 & - & 390 & 790 & 1340 & 180 & 360 & 540 \\
\hline
\end{tabular}

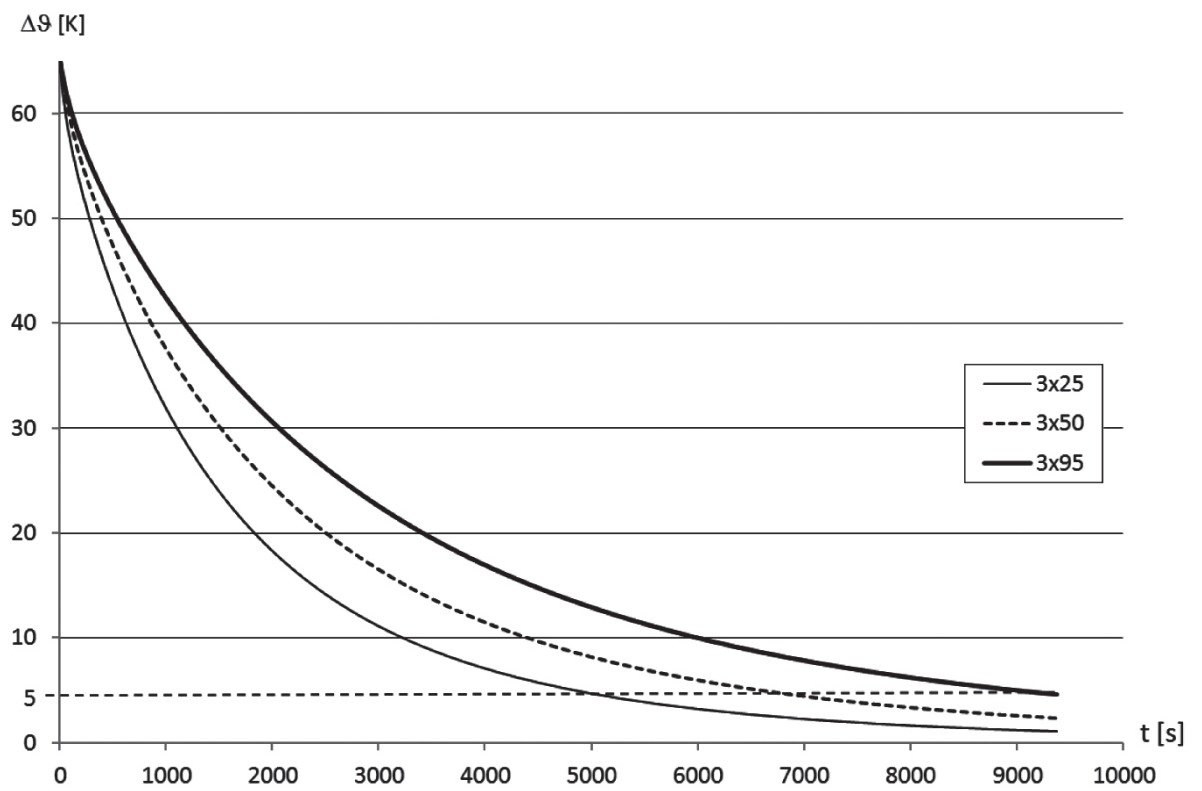

Fig. 3. Insulation temperature rise during cooling of cables with different conductors' cross-sectional areas after being heated by load current for $\$ 260$ min duty-type

Table 3 depicts the cooling time for cables heated with permissible load resulting from the type of operation (current specified in Tab. 1). The results of these calculations are to be treated indicatively, as in reality, the cooling conditions may differ from those assumed. Some factors that may influence the cooling process are the temperature of the surroundings, air movement, proximity of other cables, routing of the cables, etc. The values of time shown in the table correspond to the temperature of the conductors; the variability of temperature for other elements is different due to the inertia of the heat-conduction processes.
Table 3

Cooling duration (down to $30^{\circ} \mathrm{C}$ ) after cable has been heated by current for different duty-types

\begin{tabular}{|c|c|c|}
\hline \multirow{2}{*}{$\begin{array}{c}\text { Nominal cross-sectional } \\
\text { area of conductors }\left[\mathbf{m m}^{2}\right]\end{array}$} & \multicolumn{2}{|c|}{$\begin{array}{c}\text { Cooling time (in seconds) } \\
\text { to } 30^{\circ} \mathbf{C} \text { for cables heated } \\
\text { by current for duty-type: }\end{array}$} \\
\cline { 2 - 3 } & S2 60 min & S2 15 min \\
\hline 25 & 4870 & 2030 \\
\hline 35 & 5720 & 2840 \\
\hline 50 & 6610 & 3660 \\
\hline 70 & 7710 & 4690 \\
\hline 95 & 8970 & 5860 \\
\hline
\end{tabular}


It follows from the calculations that the cooling time of a cable depends on the heat-inducing duty type. The cooling time for duty S2 $15 \mathrm{~min}$ is considerably shorter than for duty S2 $60 \mathrm{~min}$; this can be explained by the fact that, for a greater but shorter-lasting duty (S2 $15 \mathrm{~min}$ ), the amount of heat accumulated in the cable is less than for smaller but longerlasting duty (S2 $60 \mathrm{~min}$ ). This in turn stems from the fact that, as the duty terminates, the temperature of the cable's outer layers is heavily dependent on the duty-type. For instance, if a cable with a conductor area of $95 \mathrm{~mm}^{2}$ is considered, the temperature of the coolest point of the outer sheath after completing operation cycle S2 $15 \mathrm{~min}$ is equal to $36^{\circ} \mathrm{C}$, whereas for cycle S2 $60 \mathrm{~min}$, it amounts to $53^{\circ} \mathrm{C}$.

\section{CONCLUSIONS}

On the basis of the analyses and calculations conducted in this paper, the following conclusions may be drawn:

1) A cable's current-carrying capacity depends on the duty type of the supplied machine, and this capacity may vary in value from a few to up to several dozen percentage points greater in the case of short-term duty than with continuous load. These values depend on the period of duty as well as the nominal cross-section of the cable's conductor.

2) Long-lasting duty of increased current results in the insulation's long-term exceedance of permissible temperatures. These consequences can be especially damaging for cables with a smaller crosssection of conductors.
3) The time needed for a cable to cool down to a temperature similar to that of the surroundings is linked to the cross-section of the cable's conductors and type of operation. This value of time ranges from approx. $2.5 \mathrm{~h}$ (for cables with greater cross-section conductors heated with duty S2 $60 \mathrm{~min}$ ) to slightly above $30 \mathrm{~min}$ (for cables with smaller cross-sections for duty S2 $15 \mathrm{~min}$ ).

The methodology presented in this article can be used for calculating the current-carrying capacity of cables of any construction and any type of duty.

\section{References}

[1] PN-G-42060:1997 Elektroenergetyka kopalniana - Obciażalność przewodów oponowych $i$ kabli stosowanych $w$ podziemnych wyrobiskach zakładów górniczych.

[2] PN-EN 60034-1:2011 Maszyny elektryczne wirujące - Część 1. Dane znamionowe i parametry.

[3] Boron S.: Model matematyczny procesów cieplnych zachodzacych $w$ górniczych kablach i przewodach oponowych i jego zastosowanie do analizy obciążalności prądowej, Doctoral dissertation, Gliwice 1999 [unpublished].

[4] Szargut J. (red.): Modelowanie numeryczne pól temperatury, WNT, Warszawa 1992.

SERGIUSZ BORON, Ph.D., Eng. Department of Electrical Engineering and Automation in Industry Faculty of Mining and Geology Silesian University of Technology ul. Akademicka 2A, 44-100 Gliwice, Poland sergiusz.boron@polsl.pl 


\title{
Wpływ charakteru obciążenia na obciążalność prądową górniczych przewodów oponowych
}

\begin{abstract}
$W$ artykule opisano metodykę wyznaczania obciażalności przewodów dla obciażeń innych niż dtugotrwałe. Przedstawiono wyniki przykładowych obliczeń obciązalności górniczych przewodów oponowych dla obciażenia dorywczego o różnym czasie trwania, a także czasu stygnięcia do temperatury zblizonej do temperatury otoczenia.
\end{abstract}

Słowa kluczowe: obciażalność pradowa, elektroenergetyczne przewody górnicze

\section{WPROWADZENIE}

Aktualna norma [1] dotycząca obciążalności prądowej górniczych kabli i przewodów oponowych zawiera zasady doboru dotyczące obciążalności długotrwałej i chwilowej (przy zwarciu). Norma [2] dotycząca parametrów znamionowych silników wyróżnia, poza obciążeniem długotrwałym, inne rodzaje obciążenia silników elektrycznych. Obciążenie może być opisane liczbowo (moc obciążenia zmienia się w czasie w znany sposób), graficznie lub przez wybranie jednego z predefiniowanych rodzajów obciążenia S1 do S10 (rzeczywiste obciążenie nie powinno powodować większych skutków cieplnych niż wybrane). Obciążenie S1 odpowiada pracy ciągłej przy stałym obciążeniu, obciążenie S2 - pracy dorywczej, S3 do S5 - pracy przerywanej, natomiast S6 do S10 pracy ciągłej przy zmiennym obciążeniu. Pracę dorywczą cechuje niezmieniające się obciążenie trwające przez określony czas, krótszy niż czas potrzebny do osiągnięcia temperatury ustalonej, po czym następuje okres postoju trwający dostatecznie długo, aby temperatura silnika nie różniła się więcej niż o określoną wartość od temperatury otoczenia (rys. 1). Praca przerywana jest definiowana jako sekwencja jednakowych cykli mogących (w zależności od rodzaju pracy) zawierać okresy obciążenia, postoju, rozruchu i hamowania.

Producent silnika powinien określić znamionową moc obciążenia dla danego rodzaju pracy, a jeżeli rodzaj pracy nie jest podany, to moc odnosi się do ob- ciążenia S1. Jeżeli dodatkowe elementy wyposażenia są częścią maszyny, parametry znamionowe odnoszą się również do tych elementów. Takimi elementami maszyn mogą być odcinki przewodów, oczywiste jest, że również przewody i kable zasilające maszynę obciążone są w podobny sposób jak jej silnik. Nieuwzględnienie przy doborze przekroju znamionowego żył roboczych kabli i przewodów innego rodzaju obciążenia niż S1 może prowadzić do:

- nieuzasadnionego zawyżenia przekroju, a co za tym idzie, zwiększenia kosztów instalacji, jeżeli rzeczywiste obciążenie wywołuje mniejsze przyrosty temperatury niż praca ciągła;

- nadmiernych przyrostów temperatury, jeżeli rzeczywiste obciążenie wywołuje większe obciążenie cieplne niż praca ciągła (może to być wynikiem częstych i ciężkich rozruchów i hamowania elektrycznego, np. rodzaj pracy S4 lub S5).

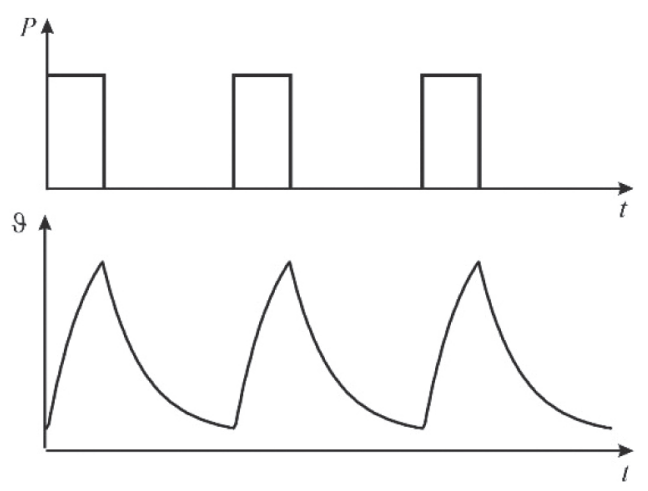

Rys. 1. Przebieg temperatury $\vartheta$ i obciążenia $P$ dla pracy dorywczej (S2) 
W wielu przypadkach, szczególnie w odniesieniu do maszyn pracujących w kompleksach ścianowych (np. kombajny i przenośniki ścianowe), rzeczywisty charakter obciążenia jest zbliżony do przerywanego, ale z uwagi na losowy charakter zmian obciążenia, przyporządkowanie jednego ze znormalizowanych rodzajów pracy jest dla tego typu maszyn w zasadzie niemożliwe. W odniesieniu do innych maszyn (przykładem mogą być pompy pracujące cyklicznie) możliwe jest określenie z zadowalającą dokładnością jednego $\mathrm{z}$ predefiniowanych $\mathrm{w}$ normie [2] rodzajów pracy. W niniejszym artykule przedstawiono analizę procesów nagrzewania i stygnięcia przewodów przy pracy dorywczej. Przedstawioną metodykę obliczeń i analiz można zastosować również do innych rodzajów obciążenia.

\section{WYZNACZANIE OBCIAŻALNOŚCI PRADOWEJ}

Wartości obciążalności prądowej długotrwałej dla poszczególnych grup górniczych kabli i przewodów oponowych podane są w normie [1], jednakże ze względu na to, że kable podobnych typów produkowane przez różnych producentów mogą się nieco różnić konstrukcją, obciążalność podawana przez producenta może nieco się różnić od określonej w normie. Różnice te nie przekraczają 2-3\% i powodowane są różną średnicą żył roboczych lub grubością poszczególnych elementów konstrukcyjnych. Wartości obciążalności mogą być wyznaczane w sposób doświadczalny lub obliczeniowo. Doświadczalne wyznaczanie obciążalności jest niepraktyczne i wymaga długotrwałych pomiarów, które należy wykonać dla wszystkich przekrojów znamionowych każdego typu kabla i przewodu. Wśród metod obliczeniowych najstarszą i do chwili obecnej najbardziej rozpowszechnioną metodą obliczania obciążalności prądowej przewodów elektrycznych jest metoda oparta na tzw. cieplnym prawie Ohma. Wymaga ona stosowania wielu założeń upraszczających i współczynników geometrii wyznaczonych w sposób przybliżony lub empiryczny. W przypadku nietypowych konstrukcji przewodów lub niekonwencjonalnego sposobu ich ułożenia, jej stosowanie może prowadzić do niedokładnych wyników [3]. Przy wyznaczaniu obciążalności dla obciążenia przerywanego lub dorywczego, konieczne jest przyjęcie dalszych założeń upraszczających (np. do- tyczących niezmienności cieplnej stałej czasowej). Dodatkowo pojawiająca się w wielu zagadnieniach nieliniowość powoduje, że dokładność obliczeń, jaką zapewniają modele uproszczone, często okazuje się niewystarczająca.

Ruch ciepła w wyniku przewodzenia opisany jest równaniem Fouriera, zgodnie z którym natężenie strumienia cieplnego $q$ jest proporcjonalne do gradientu temperatury $\vartheta$ :

$$
q=-\lambda \operatorname{grad} \vartheta
$$

gdzie $\lambda$ - współczynnik przewodzenia ciepła.

Pole temperatury wewnątrz przewodu można opisać równaniem Fouriera-Kirchhoffa:

$$
\vartheta-\frac{\sigma c}{\lambda} \frac{\partial \vartheta}{\partial t}=-\frac{q_{v}}{\lambda}
$$

gdzie:

$c$ - pojemność cieplna właściwa $[\mathrm{J} /(\mathrm{kg} \cdot \mathrm{K})]$,

$\sigma$ - gęstość masy ciała $\left[\mathrm{kg} / \mathrm{m}^{3}\right]$,

$q_{v}$ - wydajność objętościowa źródeł ciepła $\left[\mathrm{W} / \mathrm{m}^{3}\right]$.

Poszukiwanie pola temperatury sprowadza się do rozwiązania równania (2), przy czym należy uprzednio sformułować warunki graniczne, na które składają się warunki początkowe i brzegowe.

Otrzymanie analitycznego rozwiązania równania różniczkowego opisującego pole temperatury (2) jest możliwe tylko w szczególnych przypadkach, dotyczących uproszczonych modeli o regularnych kształtach (np. w przewodach nieizolowanych). Dla przewodów izolowanych znacznie bardziej efektywne są metody numeryczne [4]. Obliczenia na potrzeby niniejszego artykułu zostały przeprowadzone $\mathrm{z}$ wykorzystaniem metody elementów skończonych (MES).

Istota MES polega na możliwości aproksymowania każdej ciągłej wielkości fizycznej (w tym przypadku temperatury) przez dyskretny model zbudowany z tzw. funkcji próbnej. Sposób tworzenia dyskretnego modelu polega na określeniu liczby punktów węzłowych w rozpatrywanym obszarze dzielących go na skończoną liczbę elementów i możliwie dokładnie odzwierciedlających jego kształt. W metodzie obliczane są wartości temperatury w węzłach, a w obrębie każdego elementu szukana temperatura jest aproksymowana pewnym wielomianem, przy czym wielomiany powinny zapewniać ciągłość temperatury na brzegach elementów. 


\section{OBLICZENIA \\ OBCIAZZŻALNOŚCI PRADDOWEJ PRZEWODÓW PRZY PRACY DORYWCZEJ}

W celu określenia możliwości zwiększenia obciążalności przewodów zasilających silniki pracujące przy obciążeniu dorywczym przeprowadzono obliczenia nagrzewania i stygnięcia górniczych przewodów elektroenergetycznych. Obliczenia przeprowadzono dla przewodów oponowych typu OnGcekż-G na na- pięcie znamionowe $0,6 / 1 \mathrm{kV}$ o przekrojach znamionowych żył roboczych od $25 \mathrm{~mm}^{2}$ do $95 \mathrm{~mm}^{2}$ (zastosowana metodyka obliczeń może być wykorzystana również w przypadku innych typów przewodów i kabli). $\mathrm{W}$ tabeli 1 przedstawiono obliczeniowe wartości obciążalności prądowej dorywczej dla pracy S2 $60 \mathrm{~min}$, S2 $30 \mathrm{~min}$ i S2 $15 \mathrm{~min}$ (dla porównania podano wartości obciążalności prądowej długotrwałej). Podano również wartości względne (w procentach), odniesione do obciążalności prądowej długotrwałej.

Tabela 1

Obliczeniowe wartości obciążalności prądowej długotrwałej i dorywczej przewodów typu OnGcekż-G

\begin{tabular}{|c|c|c|c|c|c|c|c|c|}
\hline \multirow{2}{*}{$\begin{array}{c}\text { Przekrój } \\
\text { znamionowy żyly } \\
\text { roboczej }\left[\mathbf{m m}^{2}\right]\end{array}$} & \multicolumn{2}{|c|}{ S1 (praca ciągla) } & \multicolumn{2}{|c|}{ S2 60 min } & \multicolumn{2}{c|}{ S2 30 min } & \multicolumn{2}{c|}{ S2 15 min } \\
\cline { 2 - 10 } & $\mathbf{A}$ & {$[\%]$} & $\mathbf{A}$ & {$[\%]$} & $\mathbf{A}$ & {$[\%]$} & A & {$[\%]$} \\
\hline 25 & 152 & 100 & 161 & 106 & 183 & 120 & 224 & 147 \\
\hline 35 & 187 & 100 & 202 & 108 & 236 & 126 & 292 & 156 \\
\hline 50 & 233 & 100 & 258 & 111 & 306 & 131 & 382 & 164 \\
\hline 70 & 288 & 100 & 330 & 115 & 398 & 138 & 502 & 174 \\
\hline 95 & 345 & 100 & 410 & 119 & 502 & 146 & 637 & 185 \\
\hline
\end{tabular}

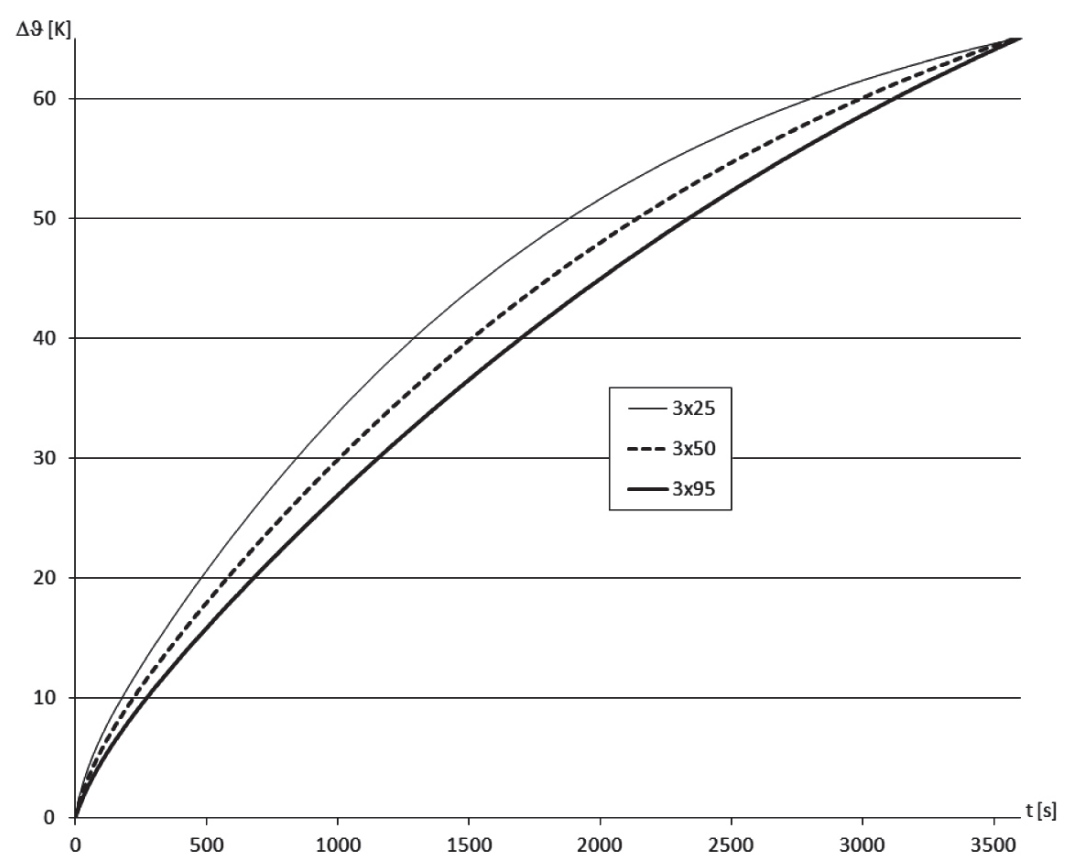

Rys. 2. Przebieg przyrostu temperatury żyt roboczych przewodu w czasie nagrzewania prądem równym obcią̇alności dla rodzaju pracy $\$ 260 \mathrm{~min}$

Na rysunku 2 przedstawiono przebieg przyrostu temperatury w funkcji czasu dla przewodów o przekroju żyły roboczej $25 \mathrm{~mm}^{2}, 50 \mathrm{~mm}^{2}$ i $95 \mathrm{~mm}^{2}$. Przedstawione przebiegi dotyczą temperatury izolacji w najgorętszym miejscu, w praktyce równej temperaturze żył roboczych. Przyjęto założenie, że w chwili $t=0$ przewód ma temperaturę równą temperaturze otoczenia $25^{\circ} \mathrm{C}$.

Należy zaznaczyć, że przebieg temperatury przy nagrzewaniu odbiega nieco od eksponencjalnego [3] ze względu na nieliniowość zagadnienia - współczynnik oddawania ciepła do otoczenia w rzeczywistych 
układach zależny jest od temperatury powierzchni oddającej ciepło. Z tego względu formalnie nie można mówić o wartości cieplnej stałej czasowej, widoczny jest jednak wolniejszy przyrost temperatury przewodów o większym przekroju żył roboczych.

Utrzymywanie się obciążenia przez okres dłuższy niż wynikający z założonego czasu pracy spowoduje przekroczenie temperatury dopuszczalnej długotrwale. Niewielkie i krótkie przekroczenia temperatury dopuszczalnej długotrwale nie mają istotnego znaczenia, jednakże przekroczenia znaczniejsze i utrzymujące się przez dłuższy czas niekorzystnie wpływają na trwałość kabla. W tabeli 2 przedstawiono czas, po którym dopuszczalny przyrost temperatury zostanie przekroczony o odpowiednio $10 \mathrm{~K}, 20 \mathrm{~K}$ i $30 \mathrm{~K}$.
W normie [2] dotyczącej maszyn elektrycznych wirujących minimalny okres postoju definiowany jest jako czas potrzebny do takiego ochłodzenia maszyny, aby temperatura zarówno jej, jak i czynnika chłodzącego nie różniły się bardziej niż o $2 \mathrm{~K}$. Ze względu na to, że kable i przewody są chłodzone jedynie powietrzem w sposób niewymuszony, w niniejszym artykule przyjęto, że okres postoju powinien być na tyle długi, aby spowodować ochłodzenie kabla (przewodu) do temperatury nie wyższej niż o $5 \mathrm{~K}$ od temperatury otoczenia. Przebieg przyrostu temperatury izolacji w czasie stygnięcia dla przewodów o różnych przekrojach znamionowych żył roboczych przedstawiono na rysunku 3.

Tabela 2

Czas [s], po którym temperatura dopuszczalna długotrwale izolacji $\left(90^{\circ} \mathrm{C}\right)$ zostanie przekroczona o $10 \mathrm{~K}, 20 \mathrm{~K}$ lub $30 \mathrm{~K}$ przy obciążeniu kabla przez okres dłuższy niż określony rodzajem pracy

\begin{tabular}{|c|c|c|c|c|c|c|c|c|c|}
\hline \multirow{2}{*}{$\begin{array}{c}\text { Przekrój } \\
\text { znamionowy żyly } \\
\text { roboczej }\left[\mathbf{m m}^{2}\right]\end{array}$} & \multicolumn{3}{|c|}{ S2 60 min } & \multicolumn{3}{c|}{ S2 30 min } & \multicolumn{3}{c|}{ S2 15 min } \\
\cline { 2 - 11 } & $\mathbf{1 0 ~ K}$ & $\mathbf{2 0 ~ K}$ & $\mathbf{3 0} \mathbf{K}$ & $\mathbf{1 0 ~ K}$ & $\mathbf{2 0 ~ K}$ & $\mathbf{3 0} \mathbf{K}$ & $\mathbf{1 0} \mathbf{K}$ & $\mathbf{2 0 ~ K}$ & $\mathbf{3 0 ~ K}$ \\
\hline 25 & - & - & - & 610 & 1570 & - & 220 & 430 & 680 \\
\hline 35 & 4160 & - & - & 520 & 1210 & 2280 & 200 & 400 & 630 \\
\hline 50 & 2050 & - & - & 460 & 1020 & 1770 & 190 & 380 & 590 \\
\hline 70 & 1550 & 5920 & - & 430 & 930 & 1520 & 180 & 370 & 560 \\
\hline 95 & 1230 & 3300 & - & 390 & 790 & 1340 & 180 & 360 & 540 \\
\hline
\end{tabular}

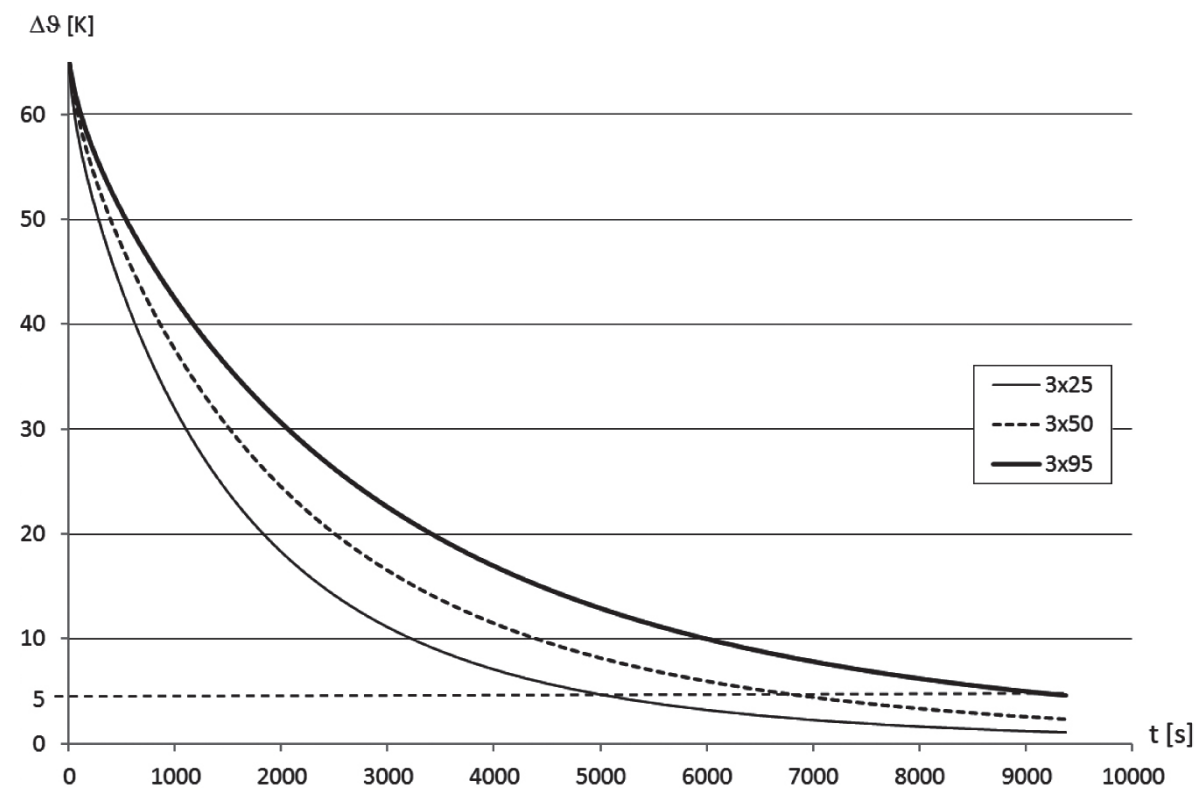

Rys. 3. Przebieg przyrostu temperatury izolacji w czasie stygnięcia przewodów o różnym przekroju żyt roboczych nagrzanych pradem obciażenia dla rodzaju pracy S2 $60 \mathrm{~min}$ 
Tabela 3 zawiera obliczeniowe wartości czasu stygnięcia dla przewodów nagrzanych obciążeniem dopuszczalnym wynikającym z rodzaju pracy (prądem podanym w tab. 1). Wyniki obliczeń należy traktować jako orientacyjne, gdyż w rzeczywistości warunki chłodzenia mogą być inne niż przyjęte do obliczeń. Istotny wpływ na przebieg procesu chłodzenia może mieć: temperatura otoczenia, ruch powietrza, obecność innych kabli w pobliżu, sposób ułożenia itp. czynniki. Czasy podane w tabeli odnoszą się do temperatury żył roboczych, przebieg temperatury innych elementów przewodu jest inny z uwagi na bezwładność procesu przewodzenia ciepła.

\section{Tabela 3}

Czas potrzebny do osiągnięcia przez izolację temperatury $30^{\circ} \mathrm{C}$

w procesie stygnięcia po nagrzaniu prądem w przypadku różnych rodzajów pracy

\begin{tabular}{|c|c|c|}
\hline \multirow{2}{*}{$\begin{array}{c}\text { Przekrój znamionowy } \\
\text { żyly roboczej }\left[\mathbf{m m}^{2}\right]\end{array}$} & \multicolumn{2}{|c|}{$\begin{array}{c}\text { Czas stygnięcia }[\mathbf{s}] \\
\text { do temperatury } \mathbf{3 0} \\
\text { dla } \mathbf{C} \\
\text { drzewodu nagrzanego } \\
\text { obciążeniem }\end{array}$} \\
\cline { 2 - 3 } & w przypadku rodzaju pracy: \\
\hline 25 & 4870 & 2030 \\
\hline 35 & 5720 & 2840 \\
\hline 50 & 6610 & 3660 \\
\hline 70 & 7710 & 4690 \\
\hline 95 & 8970 & 5860 \\
\hline
\end{tabular}

Jak wynika z obliczeń, czas stygnięcia przewodu o danym przekroju żył roboczych zależy od rodzaju pracy powodującej nagrzanie. Czas stygnięcia dla pracy S2 15 min jest znacząco krótszy niż dla pracy S2 60 min, co można wytłumaczyć faktem, że przy większym, ale krócej trwającym obciążeniu (S2 15 min), ciepło zakumulowane w przewodzie jest mniejsze niż przy obciążeniu mniejszym, ale dłuższym (S2 $60 \mathrm{~min}$ ). Wynika to z tego, że w momencie ustania obciążenia temperatura zewnętrznych warstw przewodu jest silnie zależna od rodzaju pracy. Przykładowo, w przypadku przewodu o przekroju żył roboczych $95 \mathrm{~mm}^{2}$, po zakończeniu cyklu pracy S2 15 min temperatura obliczeniowa najchłodniejszego punktu opony wynosi $36^{\circ} \mathrm{C}$, natomiast po cyklu S2 $60 \mathrm{~min}$ jest to $53^{\circ} \mathrm{C}$.

\section{WNIOSKI I UWAGI KOŃCOWE}

Na podstawie analiz i obliczeń przeprowadzonych w niniejszej pracy można wysnuć następujące wnioski:

1) Obciążalność prądowa przewodów zależna jest od rodzaju pracy zasilanych maszyn, w przypadku obciążenia dorywczego obciążalność ta może być od kilku do kilkudziesięciu procent większa niż obciążalność długotrwała. Wartości te zależne są od czasu trwania obciążenia oraz przekroju znamionowego żył roboczych przewodu.

2) Skutkiem zbyt długo trwającego obciążenia zwiększonym prądem (przekroczenie czasu określonego rodzajem pracy) jest przekroczenie temperatury dopuszczalnej długotrwale izolacji. Skutki te mogą być szczególnie niekorzystne dla przewodów o mniejszym przekroju żył roboczych.

3) Czas stygnięcia przewodów do temperatury zbliżonej do temperatury otoczenia (osiągnięcie tej temperatury jest warunkiem uznania rodzaju pracy maszyny jako dorywczej) zależy od przekroju żył przewodu oraz od rodzaju pracy. Czas ten wynosi od ok. 2,5 h (dla przewodów o większym przekroju żył nagrzanych pracą S2 $60 \mathrm{~min}$ ) do nieco powyżej 30 min (dla przewodów o mniejszym przekroju dla rodzaju pracy S2 $15 \mathrm{~min}$ ).

Przedstawiona w artykule metodyka obliczeń może być wykorzystana do obliczeń obciążalności prądowej przewodów oponowych o dowolnej budowie przy dowolnym rodzaju obciążenia.

\section{Literatura}

[1] PN-G-42060:1997: Elektroenergetyka kopalniana - Obciążalność przewodów oponowych i kabli stosowanych $w$ podziemnych wyrobiskach zakładów górniczych.

[2] PN-EN 60034-1:2011 Maszyny elektryczne wirujące - Część 1: Dane znamionowe i parametry.

[3] Boron S.: Model matematyczny procesów cieplnych zachodzacych w górniczych kablach i przewodach oponowych i jego zastosowanie do analizy obciażalności prądowej, Rozprawa doktorska, Gliwice 1999 [niepublikowana].

[4] Szargut J. (red.): Modelowanie numeryczne pól temperatury, WNT, Warszawa 1992.

dr inż. SERGIUSZ BORON

Katedra Elektrotechniki i Automatyki Przemystowej

Wydziat Górnictwa i Geologii Politechnika Śląsa

ul. Akademicka 2A, 44-100 Gliwice sergiusz.boron@polsl.pl 